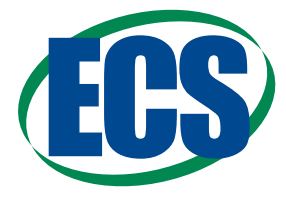

\title{
Durability of Unsupported Pt-Ni Aerogels in PEFC Cathodes
}

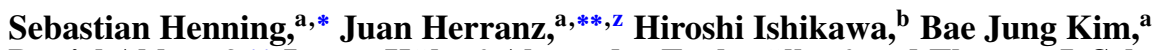 \\ Daniel Abbott, ${ }^{\mathrm{a}, * *}$ Laura Kühn, ${ }^{\mathrm{c}}$ Alexander Eychmüller, ${ }^{\mathrm{c}}$ and Thomas J. Schmidt ${ }^{\mathrm{a}, \mathrm{d}, * *}$ \\ ${ }^{a}$ Electrochemistry Laboratory, Paul Scherrer Institut, 5232 Villigen, Switzerland \\ ${ }^{b}$ Interdisciplinary Graduate School of Medicine and Engineering, University of Yamanashi, Kofu 400-8511, Japan \\ ${ }^{c}$ Physical Chemistry, Technische Universität Dresden, 01062 Dresden, Germany \\ ${ }^{d}$ Laboratory of Physical Chemistry, ETH Zurich, 8093 Zurich, Switzerland
}

\begin{abstract}
The commercial success of polymer electrolyte fuel cells (PEFCs) depends on the development of Pt-based oxygen reduction reaction (ORR) catalysts with greater activity and stability to reduce the amount of expensive noble metal per device. To advance toward this goal, we have tested a novel class of unsupported bimetallic alloy catalysts (aerogels) as the cathode material in PEFCs under two accelerated stress test conditions and compared it to a state-of-the-art carbon-supported benchmark $(\mathrm{Pt} / \mathrm{C})$. The investigated $\mathrm{Pt}_{3} \mathrm{Ni}$ aerogel shows little degradation under high potential conditions $(>1.0 \mathrm{~V})$ which can occur during fuel starvation and start-up/shutdown of the cell. If tested under the same conditions, the Pt/C benchmark displays significant losses of electrochemical surface area and ORR activity due to carbon support corrosion as observed in cross section and transmission electron microscopy analysis. When testing the durability upon extended load cycling $(0.6-1.0 \mathrm{~V}), \mathrm{Pt}_{3} \mathrm{Ni}$ aerogel demonstrates less stability than $\mathrm{Pt} / \mathrm{C}$ which is related to the severe Ni leaching from the alloy under such conditions. These findings highlight the advantages of using unsupported ORR catalysts in PEFCs and point to the reduction of non-noble metal dissolution as the next development step.

(C) The Author(s) 2017. Published by ECS. This is an open access article distributed under the terms of the Creative Commons Attribution 4.0 License (CC BY, http://creativecommons.org/licenses/by/4.0/), which permits unrestricted reuse of the work in any medium, provided the original work is properly cited. [DOI: 10.1149/2.0131712jes] All rights reserved.

(cc) BY
\end{abstract}

Manuscript submitted June 22, 2017; revised manuscript received July 21, 2017. Published August 17, 2017.

Polymer electrolyte fuel cells (PEFCs) currently rely on large amounts of carbon-supported platinum $(\mathrm{Pt} / \mathrm{C})$ catalysts $\quad(\approx 0.4$ $\mathrm{mg}_{\mathrm{Pt}} / \mathrm{cm}^{2}$ electrode $)$ to reduce the voltage losses due to the sluggish kinetics of the cathodic oxygen reduction reaction (ORR). ${ }^{1}$ Recent advancements in minimizing the Pt loading and associated costs were achieved by alloying platinum with other metals like $\mathrm{Ni}, \mathrm{Cu}$ and $\mathrm{Co}$ which increases the Pt mass-specific ORR activity. ${ }^{2}$ On the other hand, these catalysts suffer from significant corrosion of the carbon support and Pt nanoparticles during PEFC operation which compromises their long-term efficiency and reliability. ${ }^{3}$ To specifically mitigate the issue of support stability, researchers have developed alternative corrosionresistant supports (e.g. conductive metal oxides ${ }^{4-7}$ ), extended metal surfaces (e.g. $3 \mathrm{M}$ nanostructured thin film catalysts ${ }^{8}$ ) and unsupported materials (e.g. Pt-coated Ni, Co or $\mathrm{Cu}$ nanowires ${ }^{9-11}$ ). Pursuing this last strategy, unsupported bimetallic Pt-Ni electrocatalysts with high specific surface area $\left(\approx 30 \mathrm{~m}^{2} / \mathrm{g}_{\mathrm{Pt}}\right)$ and nanochain network structure, referred to as aerogels, were synthesized in a previous work. ${ }^{12}$ These materials reach the U.S. Department of Energy target (DOE; i.e. $440 \mathrm{~A} / \mathrm{g}_{\mathrm{Pt}}$ at $0.9 \mathrm{~V}$ vs. the reversible hydrogen electrode $\left(\mathrm{V}_{\mathrm{RHE}}\right)$ ) for automotive PEFC application when tested as thin films by the rotating disk electrode (RDE) technique, ${ }^{13}$ which is the standard tool employed by the majority of researchers in this field for initial assessment of catalyst activities. Considering that performance figures derived from such RDE experiments, often do not translate fully to the technical system, it is fundamental to also assess activity and durability in PEFCs to evaluate the real application potential of new catalysts. ${ }^{14,15}$

At present, few groups have reported promising durability in PEFCs for spray-coated membrane electrode assemblies (MEAs) prepared from unsupported catalysts. Studies by Tamaki et al. ${ }^{16}$ (on hollow Pt-Fe nanocapsules) and Lee et al. ${ }^{17}$ (on FePt nanotubes) showed outstanding retention of electrochemical surface area (ECSA) and performance in $\mathrm{H}_{2} / \mathrm{O}_{2}$ polarization (I/E) curves for 10000 potential cycles between 1.0 and $1.5 \mathrm{~V}_{\mathrm{RHE}}$, and upon constant exposure to a high potential of $1.4 \mathrm{~V}_{\mathrm{RHE}}$ for three hours, respectively. However, none of those studies focused on the PEFC-performance of these materials under application-relevant conditions, i.e., using $\mathrm{H}_{2}$ and air at the anode and cathode inlet feeds, respectively. With this motivation, in a recent report we have demonstrated how the increase of porosity in the catalyst layer (CL) of $\mathrm{Pt}_{3} \mathrm{Ni}$ aerogel MEAs caused by the addition

\footnotetext{
*Electrochemical Society Student Member

**Electrochemical Society Member

${ }^{\text {z} E-m a i l: ~ j u a n . h e r r a n z @ p s i . c h ~}$
}

of a removable filler material greatly improves the performance in $\mathrm{H}_{2} /$ air I/E curves. ${ }^{18}$

Following this recent study, in this work the durability of $\mathrm{Pt}_{3} \mathrm{Ni}$ aerogels in the PEFC is investigated for two different accelerated stress tests (ASTs) proposed by the DOE and compared to a commercial Pt/C benchmark. The first AST exposes the catalyst to the potential regime of 1.0 to $1.5 \mathrm{~V}_{\mathrm{RHE}}$, which can occur in an operating PEFC during fuel starvation and start-up/shut-down of the cell and triggers C-support corrosion, ${ }^{5,19-22}$ and that will be referred to as 'start-stop degradation' in the following. ${ }^{23}$ The second AST which has not been investigated in the studies cited above simulates the variation in power output present during automotive application that results in potential fluctuations between $\approx 0.6$ and $\approx 1.0 \mathrm{~V}_{\mathrm{RHE}}$ causing $\mathrm{Pt}$ dissolution (and re-deposition); ${ }^{21,24-26}$ it will be denoted 'load-cycle degradation'. As we will demonstrate in this article, $\mathrm{Pt}_{3} \mathrm{Ni}$ electrodes show superior durability for start-stop degradation compared to $\mathrm{Pt} / \mathrm{C}$ due to the absence of a corrodible carbon-support. Additionally, severe $\mathrm{Ni}$-leaching from the $\mathrm{Pt}_{3} \mathrm{Ni}$ aerogel in load-cycle degradation experiments is identified as the major cause for their activity loss and inferior stability when compared to $\mathrm{Pt} / \mathrm{C}$ under these conditions.

\section{Experimental}

$\mathrm{Pt}_{3} \mathrm{Ni}$ aerogel was synthesized according to the procedure described in Reference 12 . In brief, $0.585 \mathrm{ml}$ of a $0.205 \mathrm{M} \mathrm{H}_{2} \mathrm{PtCl}_{6}$ solution ( $8 \mathrm{wt} \%$ in $\mathrm{H}_{2} \mathrm{O}$, Sigma Aldrich) and $4 \mathrm{ml}$ of a freshly prepared $10 \mathrm{mM} \mathrm{NiCl}_{2}$ solution $\left(\mathrm{NiCl}_{2}{ }^{*} 6 \mathrm{H}_{2} \mathrm{O}, 99 \%\right.$, Sigma Aldrich) were dissolved in $790 \mathrm{ml}$ of ultrapure water $(18.2 \mathrm{M} \Omega \mathrm{cm}$, Millipore) and stirred until the mixing was complete. Subsequently, $7.0 \mathrm{ml}$ of freshly prepared 0.1 $\mathrm{M} \mathrm{NaBH}_{4}$ solution (granular, 99.99\%, Sigma Aldrich) were added while stirring vigorously. A brown solution was obtained that was kept stirring for another $30 \mathrm{~min}$. Afterwards, the reaction solution was distributed among several $100 \mathrm{ml}$ vials. After about four days, black $\mathrm{Pt}_{3} \mathrm{Ni}$ hydrogel was formed at the bottom of the containers. The hydrogel was washed with water and the solvent was exchanged with acetone afterwards. The resulting anhydrous gels were subjected to critical point drying in $\mathrm{CO}_{2}$ (Critical Point Dryer 13200J-AB, SPI Supplies).

Membrane electrode assemblies (MEAs) were fabricated using $\mathrm{Pt}_{3} \mathrm{Ni}$ aerogel, $\mathrm{Pt} / \mathrm{C}$ (47 wt\%, TKK, TEC10E50E) or $\mathrm{Pt} / \mathrm{C}_{\text {graphitized }}$ (30 wt $\%$, TKK, TEC10EA30E) as the cathode catalyst (with loadings of $0.3-0.4 \mathrm{mg}_{\mathrm{Pt}} / \mathrm{cm}^{2}$ geom ), Nafion XL-100 (DuPont) as the membrane and commercial gas diffusion electrodes (Johnson Matthey, 
$0.4 \mathrm{mg}_{\mathrm{Pt}_{\mathrm{t}}} / \mathrm{cm}_{\text {geom }}^{2}$ HISPEC $9100 \mathrm{Pt} / \mathrm{HAS}$ on Sigracet GDL $25 \mathrm{BC}$ ) as the anode.

Catalyst inks for $\mathrm{Pt}_{3} \mathrm{Ni}$ electrodes were prepared as described in Reference 18 by mixing $5 \mathrm{mg}$ of catalyst, $0.7 \mathrm{mg}$ of $\mathrm{K}_{2} \mathrm{CO}_{3}(99.995 \%$ trace metals basis, Sigma Aldrich), $18 \mathrm{mg}$ of $\mathrm{Na}^{+}$-exchanged Nafion solution (prepared from a 1:2 mixture of $0.1 \mathrm{M} \mathrm{NaOH}$ and Nafion solution, ${ }^{27}$ and equal to a Nafion-to-catalyst-ratio of 0.12 ) and $1.0 \mathrm{ml}$ of an $8 \mathrm{wt} \%$ aqueous isopropanol solution (ultrapure water, $18.2 \mathrm{M} \Omega \mathrm{cm}$, Elga Purelab Ultra and isopropanol, 99.9\%, Chromasolv Plus for HPLC, Sigma Aldrich). After ultrasonication (USC100T, $45 \mathrm{kHz}, \mathrm{VWR}$ ) for 30 minutes and spray coating (using a frame to confine the coating to the active area of $1 \mathrm{~cm}^{2}$ ), the resulting catalyst coated membranes (CCMs) were immersed into $1 \mathrm{M} \mathrm{H}_{2} \mathrm{SO}_{4}$ solution ( $96 \%$, Suprapur, Merck) overnight ( $\approx 16$ hours), followed by rinsing with ultrapure water and drying under ambient conditions. The acid washing step was introduced to remove the filler material $\mathrm{K}_{2} \mathrm{CO}_{3}$ and thus to create a $\mathrm{CL}$ with increased porosity (for details see Reference 18). For $\mathrm{Pt} / \mathrm{C}$ ( $\left.\mathrm{Pt} / \mathrm{C}_{\text {graphitized }}\right)$ cathodes, $50 \mathrm{mg}$ of catalyst was mixed with $500(650) \mathrm{mg}$ of $5 \mathrm{wt} \%$ Nafion solution (equal to a Nafion-to-carbon-ratio of 1.0) and $4.5 \mathrm{ml}$ of a $20 \mathrm{wt} \%$ aqueous isopropanol solution, followed by the steps described above without the acid washing. In a last step, the CCMs were hotpressed at $120^{\circ} \mathrm{C}$ and $1 \mathrm{bar} / \mathrm{cm}^{2}$ geom for 5 minutes to a gas diffusion layer (GDL $25 \mathrm{BC}$, Sigracet) and a commercial gas diffusion electrode (see above) on the cathode and anode side, respectively.

The MEAs were placed in a differential fuel cell that allows studying the MEA under homogeneous, well-defined conditions in the absence of along-the-channel effects such as changing temperature, relative humidity $(\mathrm{RH})$ and gas concentration. ${ }^{28}$ The fuel cell used for this study was developed inhouse, featuring 5 parallel channels of $1 \mathrm{~mm}$ width over an active area of $1 \mathrm{~cm}^{2} .^{29}$ Using steel spacers with defined thickness, cell compression was set such that $\approx 25 \%$ compression of the gas diffusion media was obtained. ${ }^{29,30}$ The MEA break-in started by drawing the maximum current that would yield cell potentials $>0.6 \mathrm{~V}$ in $\mathrm{H}_{2} / \mathrm{O}_{2}$ at 1.5 bar $_{\text {abs }}$ and a relative humidity $(\mathrm{RH})$ of $100 \%$ between 25 and $80^{\circ} \mathrm{C}$ for 2 hours (flow rates anode/cathode: $300 / 750 \mathrm{ml} / \mathrm{min}^{31}$, stoichiometries $\geq 30 / \geq 30$ ), followed by cooling down of the cell, activating potential cycles and a repetition of the first step (at $80^{\circ} \mathrm{C}$ ). It must be noted here that even as the applied stoichiometry ratios are significantly higher than for technical cells, the gas flow velocities remain in the same order of magnitude due to the reduced size of the device. ${ }^{28}$

Cyclic voltammograms (CVs) were measured after break-in at $25^{\circ} \mathrm{C}$ and $100 \% \mathrm{RH}$, scanning the potential between 0.075 and 1.0 $\mathrm{V}_{\mathrm{RHE}}$ at $50 \mathrm{mVs}^{-1}$ with a $\mathrm{H}_{2}$ anode flow rate of $50 \mathrm{ml} / \mathrm{min}$ and the $\mathrm{N}_{2}$ cathode flow halted just prior to the measurement. The corresponding ECSA value was averaged from the $\mathrm{H}$-adsorption and $\mathrm{H}$-desorption charges between 0.09 and $0.4 \mathrm{~V}_{\mathrm{RHE}}$ after double-layer correction, assuming a conversion factor of $210 \mu \mathrm{C} / \mathrm{cm}^{2}{ }_{\mathrm{Pt}} \cdot{ }^{32} \mathrm{H}_{2}$-crossover tests were conducted by a linear potential sweep from 0.6 to $0.1 \mathrm{~V}_{\mathrm{RHE}}$ with a scan rate of $1 \mathrm{mVs}^{-1}$ at $80^{\circ} \mathrm{C}, 100 \% \mathrm{RH}, 1.5$ bar $_{\text {abs }}$, an anode $\mathrm{H}_{2}$ flow rate of $300 \mathrm{ml} / \mathrm{min}$ and a cathode $\mathrm{N}_{2}$ flow rate of $750 \mathrm{ml} / \mathrm{min}$, respectively; ${ }^{33}$ the $\mathrm{H}_{2}$-crossover current densities typically amounted to $\approx 2 \mathrm{~mA} / \mathrm{cm}^{2}$ MEA.

All I/E curves were recorded at $80^{\circ} \mathrm{C}$ and $100 \% \mathrm{RH}$ with anode/cathode flow rates of $300 / 750 \mathrm{ml} / \mathrm{min}$ (stoichiometries $\geq$ $30 / \geq 30$ ) at 1.5 bar $_{\text {abs }}$ for either $\mathrm{H}_{2} / \mathrm{O}_{2}$ or $\mathrm{H}_{2}$ /air, using a Biologic VSP-300 potentiostat with a $10 \mathrm{~A} / 5 \mathrm{~V}$ current booster. The measurement was done galvanostatically, whereby the cell current was stabilized for 3 minutes at each data point and the data was averaged from the last 2 minutes. Concomitantly, the cell resistance $\left(\mathrm{R}_{\Omega}\right)$ was determined for each data point by galvanostatic electrochemical impedance spectroscopy (1 MHz to $1 \mathrm{~Hz}$ ). Mass- and surface-specific activites for $\mathrm{H}_{2} / \mathrm{O}_{2}$ operation were extracted at $0.9 \mathrm{~V}_{\mathrm{RHE}}$ after correcting potential and current for cell resistance and $\mathrm{H}_{2}$-crossover, respectively.

The accelerated stress tests were performed at $80^{\circ} \mathrm{C}, 100 \% \mathrm{RH}$, ambient pressure, anode $\mathrm{H}_{2}$ flow of $100 \mathrm{ml} / \mathrm{min}$ and cathode $\mathrm{N}_{2}$ flow of $100 \mathrm{ml} / \mathrm{min}$ following shortened AST protocols established by the DOE for automotive PEFC application. ${ }^{23}$ For start-stop and load-
Start-Stop Degradation Load-Cycle Degradation
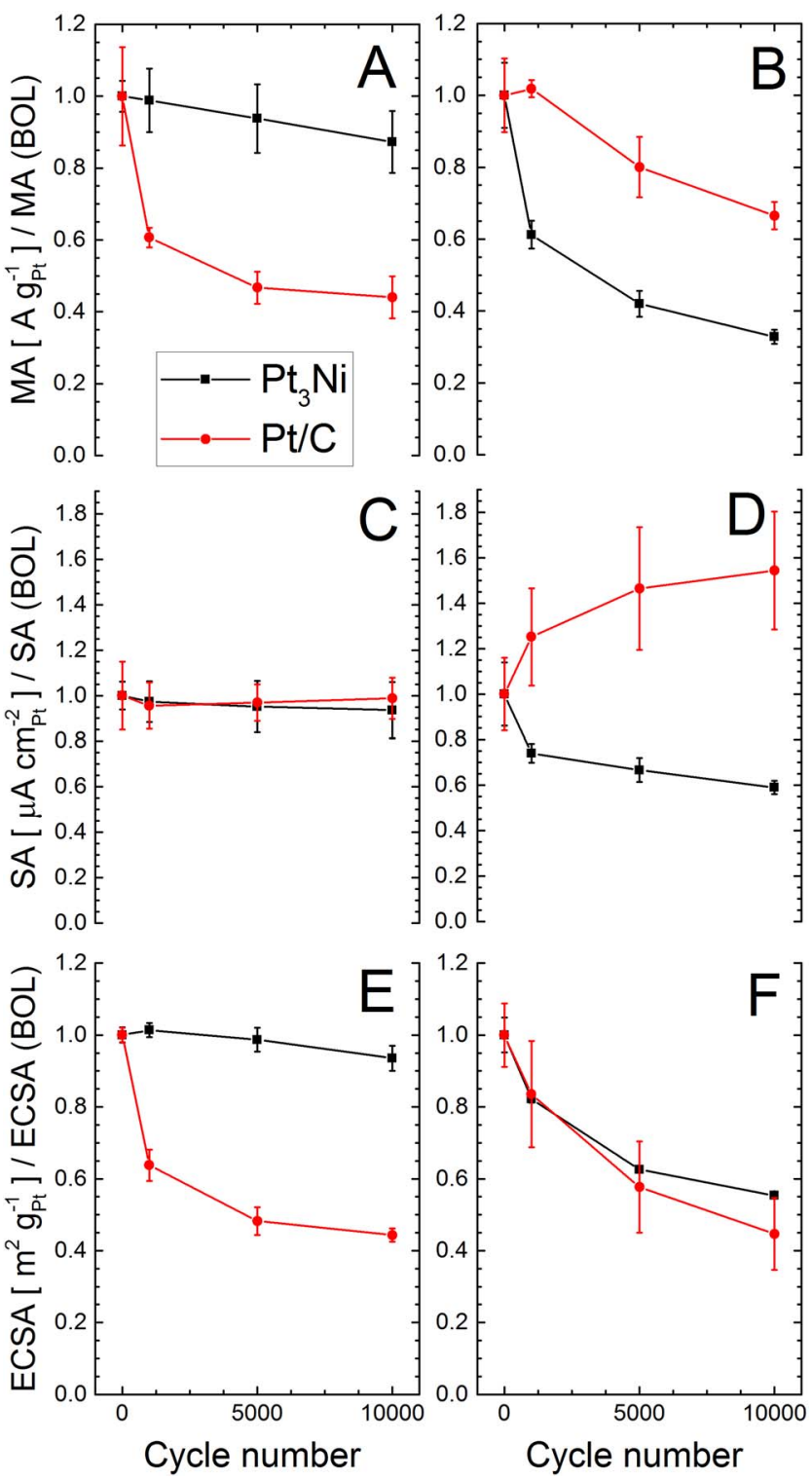

Figure 1. Average (three repetitions) MA (A, B), SA (C, D) at $0.9 \mathrm{~V}_{\mathrm{RHE}}$ and (E, F) ECSA normalized to the respective BOL values of $\mathrm{Pt}_{3} \mathrm{Ni}$ and $\mathrm{Pt} / \mathrm{C}$ MEAs (cathode loadings of $0.3-0.4 \mathrm{mg}_{\mathrm{Pt}} / \mathrm{cm}^{2}$ geom ) for start-stop (left) and load-cycle degradation (right), respectively.

cycle degradation, the potential was cycled 10000 times between 1.0 and $1.5 \mathrm{~V}_{\mathrm{RHE}}$ at $500 \mathrm{mVs}^{-1}$ and 0.6 and $1.0 \mathrm{~V}_{\mathrm{RHE}}$ at $50 \mathrm{mVs}^{-1}$, respectively. ${ }^{5,16,23}$ At designated times (1000, 5000 cycles), the ASTs were interrupted to record I/E curves and CVs (cf. above) to determine the ECSA.

Transmission electron microscopy (TEM) images and elemental composition of the catalysts were obtained on a TECNAI F30 operated at $300 \mathrm{kV}$ and equipped with an energy dispersive X-ray spectroscopy (EDX) detector. For tomography and cross section preparation with a focused ion beam-scanning electron microscope (FIB-SEM), a Zeiss NVision 40 microscope with a $\mathrm{Ga}^{+}$beam source and an EDX detector was employed.

\section{Results and Discussion}

Figures 1A, 1C and 1E (adapted from Reference 18) show the evolution of mass-specific activities (MAs), surface-specific activities 
Table I. Average values of the beginning-of-life MA, SA (at 0.9 $\left.\mathrm{V}_{\mathrm{RHE}}, 80^{\circ} \mathrm{C}, 100 \% \mathrm{RH}, \mathrm{H}_{2} / \mathrm{O}_{2}, 1.5 \mathrm{bar}_{\mathrm{abs}}\right)$ and ECSA $\left(\right.$ at $\left.25^{\circ} \mathrm{C}\right)$ of $\mathrm{Pt}_{3} \mathrm{Ni}$ aerogel and $\mathrm{Pt} / \mathrm{C}$ MEAs.

\begin{tabular}{ccc} 
& $\mathrm{Pt}_{3} \mathrm{Ni}$ & $\mathrm{Pt} / \mathrm{C}$ \\
\hline $\mathrm{MA}\left[\mathrm{A} / \mathrm{g}_{\mathrm{Pt}}\right]$ & 113 & 120 \\
$\mathrm{SA}\left[\mu \mathrm{A} / \mathrm{cm}^{2} \mathrm{Pt}\right]$ & 526 & 233 \\
$\mathrm{ECSA}\left[\mathrm{m}^{2} / \mathrm{g}_{\mathrm{Pt}}\right]$ & 29 & 69
\end{tabular}

(SAs) and ECSAs for the start-stop degradation test of 10000 potential cycles between 1.0 and $1.5 \mathrm{~V}_{\mathrm{RHE}}$ at $500 \mathrm{mVs}^{-1}$, normalized to the respective beginning-of-life (BOL) values. The latter are summarized in Table I, whereby the experimental data for the benchmark catalyst is in good agreement with literature reports for the same material. ${ }^{32}$ After the start-stop $\mathrm{AST}, \mathrm{Pt}_{3} \mathrm{Ni}$ aerogel cathodes show only a minor decrease of the MA, SA and ECSA. The aerogel thus behaves similarly to the unsupported hollow Pt-Fe nanocapsule catalyst that was recently investigated by Tamaki et al. following the same protocol. ${ }^{16} \mathrm{The} \mathrm{Pt} / \mathrm{C}$ benchmark, however, suffers from $\approx 50 \%$ loss of MA and ECSA at the end-of-life (EOL), in agreement with observations in Reference 5 using the same protocol. Additionally, the $\mathrm{Pt} / \mathrm{C}$ benchmark displays drastic performance reduction in $\mathrm{H}_{2}$ /air $\mathrm{I} / \mathrm{E}$ curves, whereas $\mathrm{Pt}_{3} \mathrm{Ni}$ again maintains the BOL performance as discernable from Figure 2A. Moreover, we conducted the same start-stop AST on a commercial Pt-catalyst implementing a graphitized carbon support $\left(\mathrm{Pt} / \mathrm{C}_{\text {graphitized }}\right.$, see Experimental section for details). As showcased in Figure SI-1 of the Supplementary Information, in the early stages of the AST, this $\mathrm{Pt} / \mathrm{C}_{\text {graphitized }}$ underwent a less severe decrease of MA and ECSA when compared to $\mathrm{Pt} / \mathrm{C}$, but by the end of the 10000 potential cycles both variables reached $\approx 50 \%$ of their BOL-values (as compared to $\approx 40 \%$ for $\mathrm{Pt} / \mathrm{C}$, cf. Figures $1 \mathrm{~A}$ and $1 \mathrm{E}$ ). Therefore, this result further highlights the enhanced stability of the $\mathrm{Pt}_{3} \mathrm{Ni}$-aerogel, even when compared to a commercial catalyst implementing a graphitized carbon support with a short-term durability better than that of Pt/C. For the rest of this study, though, we limit the comparison among degradation behaviors to the $\mathrm{Pt}_{3} \mathrm{Ni}$ aerogel and the standard (i.e., with a nongraphitized support) $\mathrm{Pt} / \mathrm{C}$ benchmark, which has received much more attention in the existing literature.

Upon load-cycle degradation tests of 10000 potential cycles between 0.6 and $1.0 \mathrm{~V}_{\mathrm{RHE}}$ at $50 \mathrm{mVs}^{-1}$ (see Figures $1 \mathrm{~B}, 1 \mathrm{D}$ and $1 \mathrm{~F}$ ) on the other hand, $\mathrm{Pt}_{3} \mathrm{Ni}$ MEAs display a severe MA reduction of $\approx 60 \%$, as opposed to moderate losses of $\approx 30 \%$ for the Pt/C benchmark. Concomitantly, the $\mathrm{SA}$ of $\mathrm{Pt}_{3} \mathrm{Ni}$ aerogel decreases by $\approx 40 \%$ whereas for $\mathrm{Pt} / \mathrm{C}$ electrodes the EOL value exceeds the BOL one by $50 \%$. Moreover, the ECSAs for both catalysts evolve similarly $(\approx 50 \%$ reduction, in agreement with literature reports on $\mathrm{Pt} / \mathrm{C}^{25}$ ) and the potential in $\mathrm{H}_{2} /$ air $\mathrm{I} / \mathrm{E}$ curves at high current densities decrease moderately $\left(\approx 50 \mathrm{mV}\right.$ at $1.5 \mathrm{~A} / \mathrm{cm}^{2}$, cf. Figure $\left.2 \mathrm{~B}\right)$.
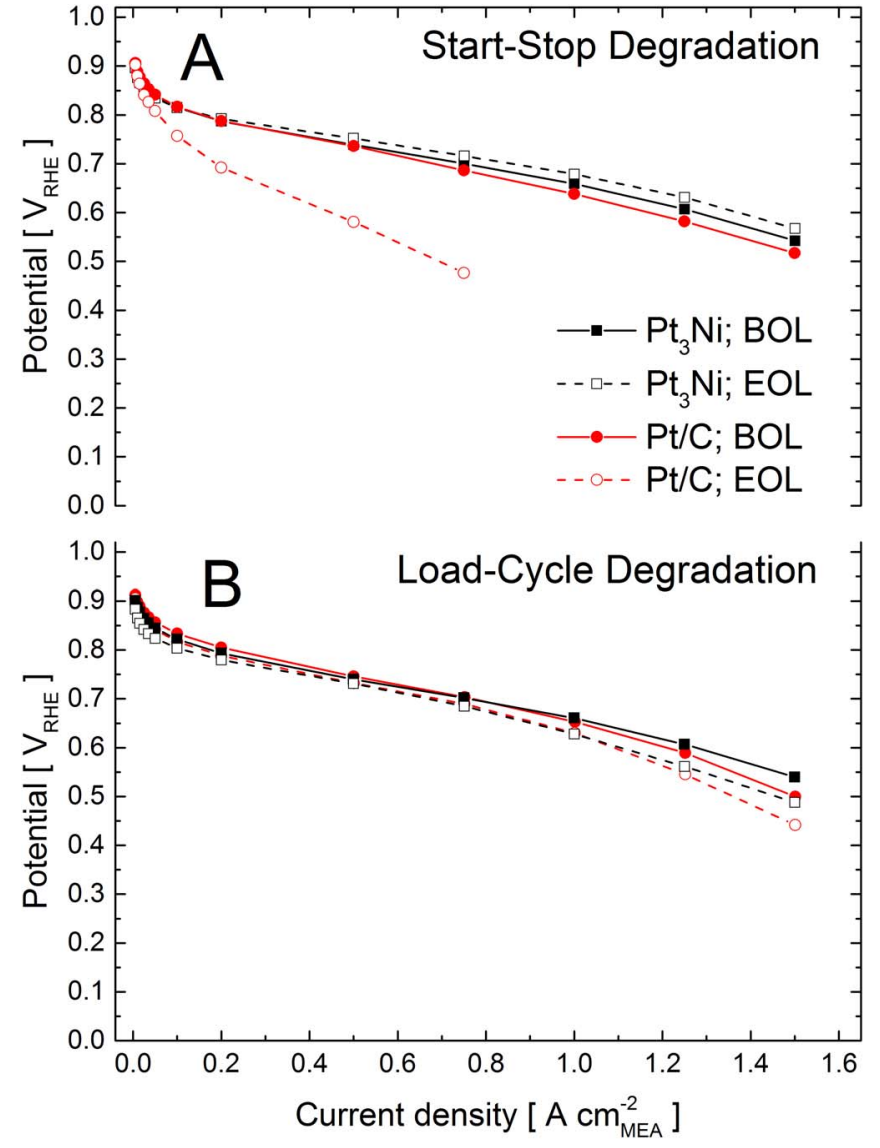

Figure 2. Beginning- and end-of-life I/E curves at $80^{\circ} \mathrm{C}, 100 \% \mathrm{RH}$, in $\mathrm{H}_{2} /$ air at 1.5 bar $_{\text {abs }}$ for the start-stop (A) and load-cycle degradation (B) of $\mathrm{Pt}_{3} \mathrm{Ni}$ and $\mathrm{Pt} / \mathrm{C}$ MEAs (cathode loadings of $0.3-0.4 \mathrm{mg}_{\mathrm{Pt}} / \mathrm{cm}^{2}$ geom).

To explain the observed degradation of $\mathrm{Pt}_{3} \mathrm{Ni}$ aerogel vs. $\mathrm{Pt} / \mathrm{C}$ MEAs during the ASTs, beginning- and end-of-life samples were analyzed at the micro- and nanoscale to complement the electrochemical characterization in Figures 1 and 2. First, cross sections of the catalyst layers (CLs) were cut with a focused-ion beam (FIB) and captured by scanning electron microscopy (SEM). Qualitative comparison of the cross section images for the $\mathrm{Pt}_{3} \mathrm{Ni} \mathrm{CL}$ at $\mathrm{BOL}$ (Figure $3 \mathrm{~A}$ ) with the ones at EOL after start-stop (Figure 3B) and after load-cycle degradation (Figure 3C) does not reveal any significant morphology or porosity changes. To support this observation by a quantitative parameter, the thickness of the CL was measured in at least three different locations and normalized to the Pt loading to allow for a comparison
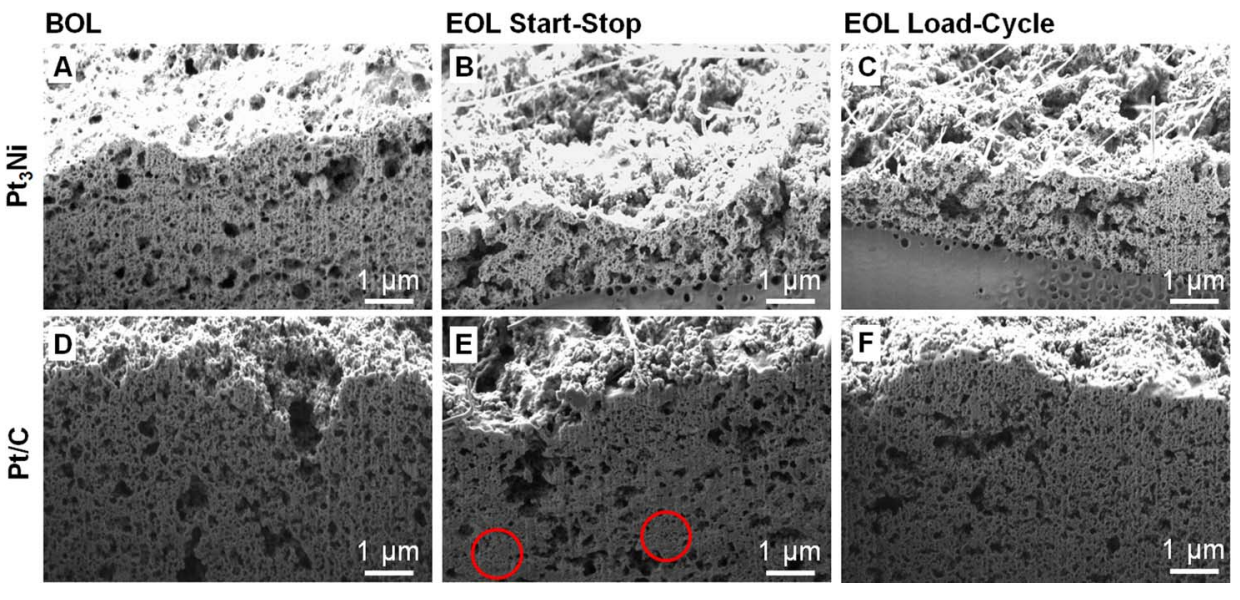

Figure 3. Representative cross section SEM images for catalyst layers of $\mathrm{Pt}_{3} \mathrm{Ni}$ aerogel (top row) and $\mathrm{Pt} / \mathrm{C}$ (bottom row) at the beginningof-life (A, D) and after start-stop (B, E) and load-cycle degradation (C, F). Note that only the top part of the catalyst layer is visible for $\mathrm{Pt} / \mathrm{C}$ at the shown magnification. The red circles highlight catalyst layer domains in which the porous structure has almost vanished. 


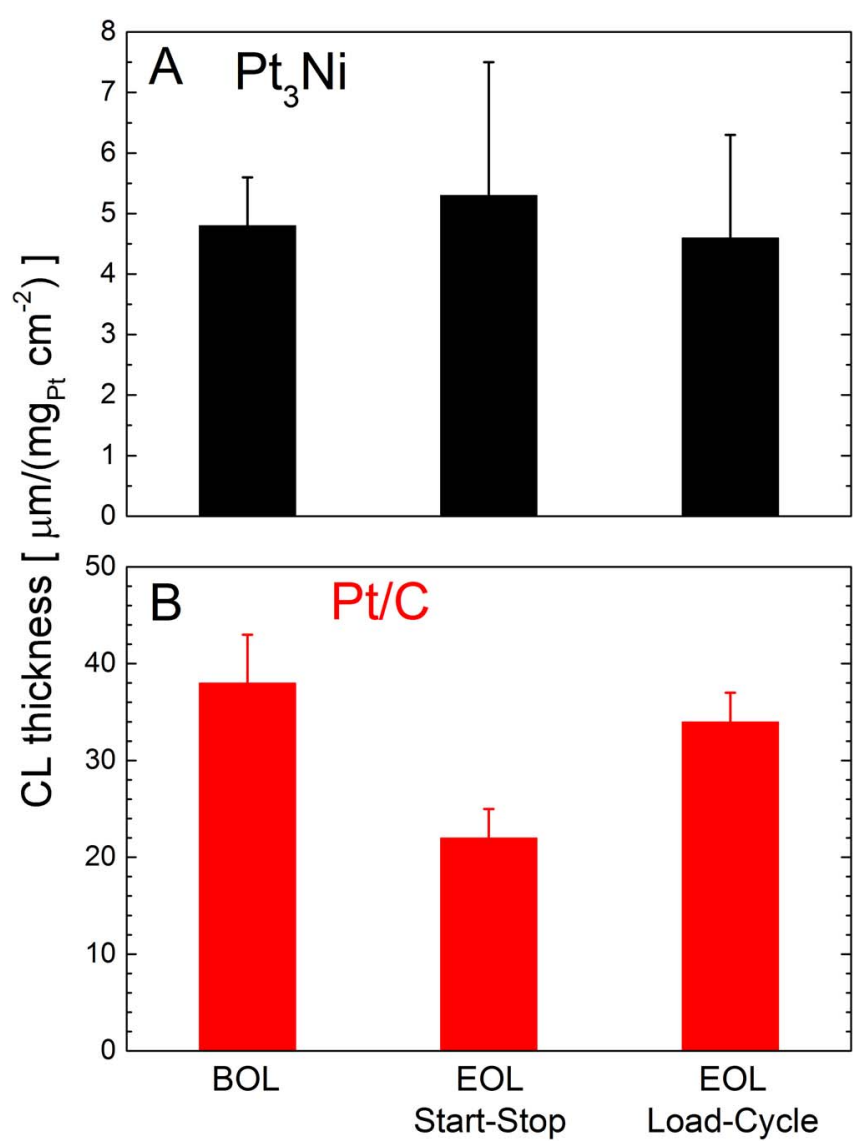

Figure 4. Catalyst layer thicknesses normalized to $\mathrm{Pt}$ loading for CLs of $\mathrm{Pt}_{3} \mathrm{Ni}$ aerogel (A) and Pt/C (B) at the beginning-of-life and after start-stop and loadcycle degradation.

between the different electrodes (BOL, EOL start-stop, EOL loadcycle). As discernable from Figure 4, the EOL CL thicknesses for $\mathrm{Pt}_{3} \mathrm{Ni}$ aerogel are comparable to the one at beginning-of-life, indicating negligible variations in porosity throughout the ASTs. Changes of the latter porosity can affect the mass transport of reactants by molecular and Knudsen diffusion within the catalyst layer and alter the gas diffusion overpotential caused by $\mathrm{O}_{2}$ concentration gradients..$^{34,35}$ Variations of this overpotential can e.g. be deduced from the overall cell potential at high current densities (HCDs) in $\mathrm{H}_{2} /$ air I/E curves, i.e. in conditions of strong concentration gradients. Thus, the negligible changes in HCD performance throughout the ASTs of $\mathrm{Pt}_{3} \mathrm{Ni}$ aerogel CLs in Figure 2 are consistent with a steady gas diffusion overpotential, and support the hypothesis that the porosity regime crucial to reactant and product mass transport remains unmodified.

The corresponding SEM cross section images for $\mathrm{Pt} / \mathrm{C}$ are displayed in Figures 3D, 3E and 3F for BOL and following the startstop and load cycle ASTs, respectively. At the end of the start-stop degradation test, one can identify domains in the CL (highlighted by red circles in Figure $3 \mathrm{E}$ ) that appear far less porous than at the BOL. This observation is concomitant with $\mathrm{a} \approx 40 \%$ decrease in thickness (cf. Figure 4D) from a BOL value of $\approx 38 \mu \mathrm{m} /\left(\mathrm{mg}_{\mathrm{Pt}} \mathrm{cm}^{-2}\right.$ ) (or $\approx 33 \mu \mathrm{m} /\left(\mathrm{mg}_{\mathrm{C}} \mathrm{cm}^{-2}\right)$, which agrees with the $28 \pm 2 \mu \mathrm{m} /\left(\mathrm{mg}_{\mathrm{C}} \mathrm{cm}^{-2}\right)$ reported in literature $)^{36}$ to $\approx 23 \mu \mathrm{m} /\left(\mathrm{mg}_{\mathrm{Pt}} \mathrm{cm}^{-2}\right)$ and points to a collapse of the CL structure which can inhibit effective mass transport of reactants and that is supported by the drastic performance decline in the $\mathrm{H}_{2} /$ air I/E curves in Figure $2 \mathrm{~A}$. The $\mathrm{CL}$ collapse can be attributed to carbon support corrosion in the applied potential regimes ${ }^{20-22,37,38}$ and the resulting CL porosity decrease has been demonstrated by Schulenburg et al. ${ }^{39}$ in a FIB-SEM tomography study. On the other hand, representative cross section images before/after the load-cycle AST (Figures 3D/3F) do not indicate significant morphology/porosity changes concomitant with the negligible decrease in thickness to $\approx 34 \mu \mathrm{m} /\left(\mathrm{mg}_{\mathrm{Pt}} \mathrm{cm}^{-2}\right)$ discernable from Figure $4 \mathrm{~B}$. Again, this agrees well with the electrochemical results at the cell level, where only a minor alteration of the $\mathrm{HCD}$ performance in $\mathrm{H}_{2}$ /air curves is observed (cf. Figure 2B).

To analyze the materials' change on the nanoscale, TEM images of the catalysts at BOL and after ASTs were taken and are summarized in Figure 5 (for additional images at other magnifications see Figures SI-2 and SI-3 in the Supplementary Information). At beginning-oflife, $\mathrm{Pt}_{3} \mathrm{Ni}$ consists of a well-defined 3D network of interconnected nanoparticles with an average nanochain diameter $d_{\text {nanochain }}$ of 5-6 nm (cf. Figure 5A). ${ }^{12}$ After the start-stop test (Figure 5B), the nanochain diameter seems to be of similar size, yet the nanochains appear somewhat "smoothed", i.e. individual nanoparticle segments are less distinct. Unfortunately, it was not feasible to determine an accurate average nanochain diameter by measuring the size at multiple locations along the nanochain as in the case of the BOL sample since the catalyst layer was difficult to disperse in the process of TEM grid preparation (cf. 3D nanochain 'stacks' in low magnification images of Figure SI-2). Regardless, the finding of comparable nanochain diameters agrees well with the electrochemical results in Figure $1 \mathrm{E}$ which displays the almost constant ECSA of the $\mathrm{Pt}_{3} \mathrm{Ni}$ aerogel after 10000 degradation cycles. On the other hand, after load-cycle degradation, $\mathrm{Pt}_{3} \mathrm{Ni}$ aerogel displays a significant increase in the nanochain diameter to a value $\geq 10 \mathrm{~nm}$ (see Figure 5C), albeit this finding cannot be quantified either due to the issue of poor CL dispersibility discussed above. Assuming $d_{\text {nanochain }} \propto 1 / E C S A,{ }^{32}$ the increase in nanochain size by about a factor of two is in good agreement with the halving of the ECSA values in Figure $1 \mathrm{~F}$ at EOL.

As for the Pt/C benchmark, Figure 5D vs. Figure 5E illustrate the carbon support corrosion during start-stop degradation that was introduced above to explain the porosity decrease of the CL (Figures 3E and $4 \mathrm{~B}$ ) and the decline of high current density performance (cf. Figure $2 \mathrm{~A}$ ). This corrosion leads to domains which are completely void of Pt nanoparticles (especially at the carbon edges) and to changes in the morphology of the carbon support that, as reported in previous studies, ${ }^{40,41}$ becomes preponderantly amorphous during these startstop stress tests (see Figure SI-3). The dramatic ECSA reduction for $\mathrm{Pt} / \mathrm{C}$ in Figure 1E (estimated on the basis of the initial mass of $\mathrm{Pt}$ in the catalyst layer) is thus related to particle detachment due to carbon corrosion, whereby smaller nanoparticles exhibit an increased probability to detach, ${ }^{21}$ and not to other ECSA decreasing mechanisms leading to Pt nanoparticle growth (see below). Specifically, the negligible impact of these nanoparticle-aggregation routes is likely related to the potential regime applied in the start-stop AST (i.e., 1.0-1.5 $\mathrm{V}_{\mathrm{RHE}}$ ), which does not include sufficiently low potentials that would lead to the reduction (and dissolution/redeposition) ${ }^{42-44}$ of the Pt-(hydr)oxides passivating the nanoparticles' surface.

Complementarily, the loss of ECSA during the load-cycle degradation tests (cf. Figure 1F) is most likely caused by Ostwald ripening and particle migration/coalescence, ${ }^{21,25,26}$ which trigger the formation of larger Pt nanoparticles as discernable by comparison of Figures $5 \mathrm{D}$ and $5 \mathrm{~F}$. It has been observed that such an increase in particle size increases the surface-specific ORR activity of Pt-based catalysts, in terms caused by a positive shift of the adsorption energy of ORR impeding, oxygen-containing species $\left(\mathrm{OH}_{\mathrm{ads}}\right)$ and the subsequent presence of more sites available for the catalysis of the reaction on the nanoparticles' surface. ${ }^{3,32,45}$ Considering the universal ORR activity - ECSA relationships introduced in References 3,32,46 and 47 to express this particle size effect, the ECSA reduction in the load-cycle AST from $\approx 70 \mathrm{~m}^{2} / \mathrm{g}_{\mathrm{Pt}}$ to $\approx 30 \mathrm{~m}^{2} / \mathrm{g}_{\mathrm{Pt}}$ should result in a SA increase to $\approx 140 \%$ and a MA reduction to $\approx 60 \%$ of the respective BOL values. These estimates are very close to the actual EOL SA and MA values of $\approx 155 \%$ and $\approx 65 \%$ (vs. BOL), respectively. The remaining difference could arise from the fact that the ORR activity - ECSA relations in the above References 3,32,46,47 are based on RDE experiments in $0.1 \mathrm{M} \mathrm{HClO}_{4}$ or $\mathrm{H}_{2} \mathrm{SO}_{4}$ between 20 and $60^{\circ} \mathrm{C}$, whereas the activity values reported in this work were obtained in a PEFC at $80^{\circ} \mathrm{C}$. 


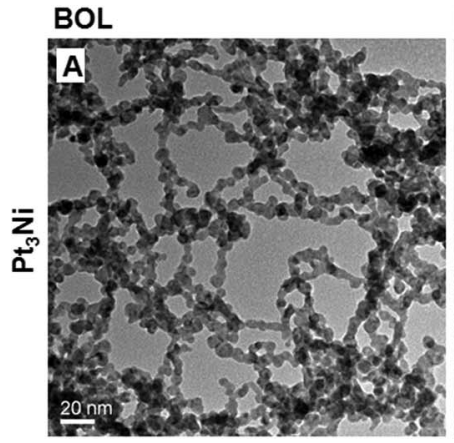

EOL Start-Stop
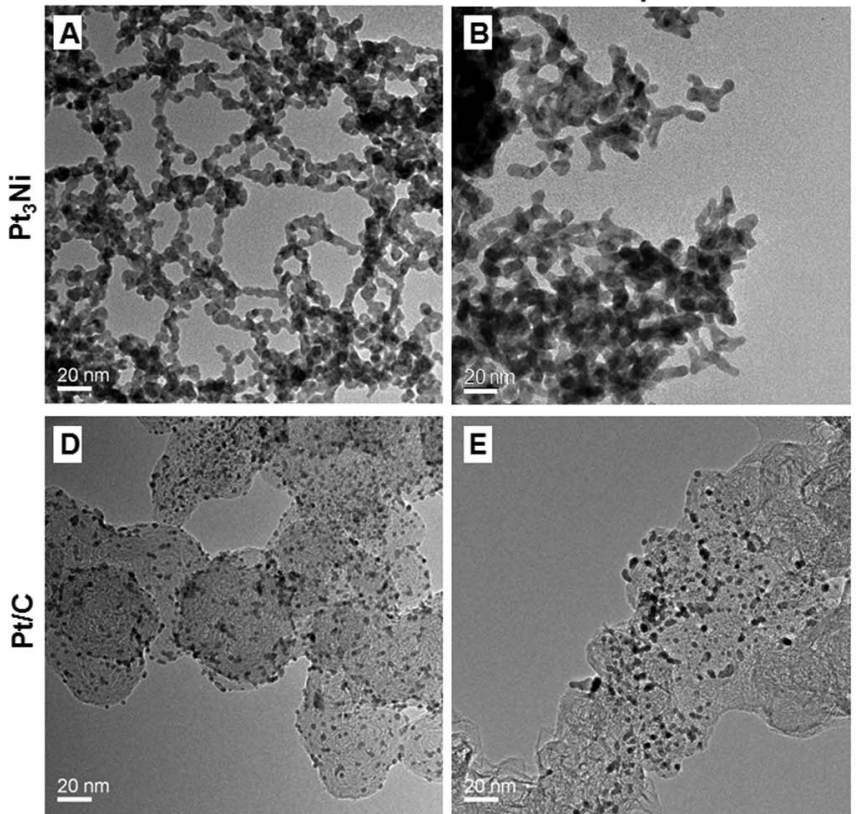

EOL Load-Cycle
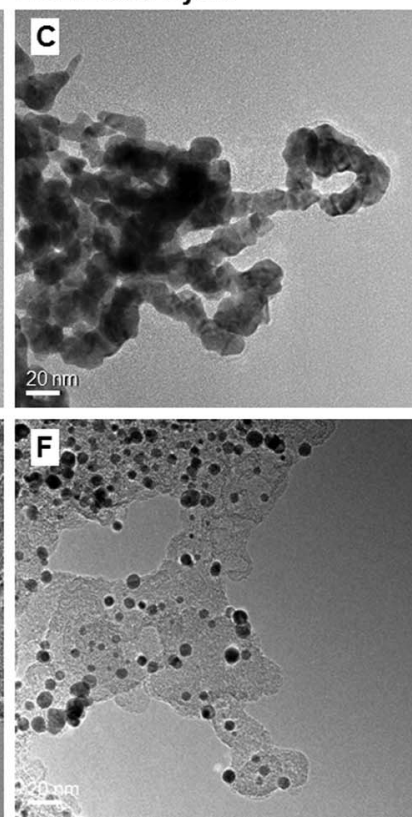

Figure 5. Representative TEM images of the $\mathrm{Pt}_{3} \mathrm{Ni}$ aerogel (top row) and $\mathrm{Pt} / \mathrm{C}$ catalyst (bottom row) at the beginning-of-life (A, D) and after start-stop (B, E) and load-cycle degradation (C, F).

While the particle size effect can account for the load-cycle degradation results of the $\mathrm{Pt} / \mathrm{C}$ benchmark, it falls short to explain the behavior of the $\mathrm{Pt}_{3} \mathrm{Ni}$ aerogel. To be precise, the ECSA reduction from $\approx 30 \mathrm{~m}^{2} / \mathrm{g}_{\mathrm{Pt}}$ to $\approx 15 \mathrm{~m}^{2} / \mathrm{g}_{\mathrm{Pt}}$ observed in this AST is expected to increase the $\mathrm{SA}$ to $\approx 135 \%$ and reduce the MA to $\approx 55 \%$ of the initial values, yet the final SA and MA amount to a mere $\approx 65 \%$ and $\approx 30 \%$ of their BOL counterparts, respectively. Consequently, other factors that can contribute to the evolution of the ORR activity need to be considered. In this respect, the leaching of the non-noble metal from Pt alloy ORR catalysts during ASTs has been reported as a cause for the concomitant activity decrease $;^{32,48}$ as an example, the resembling, $\approx 70 \% \mathrm{SA}$ loss reported for a $\mathrm{PtNi}_{3} / \mathrm{C}$ catalyst cycled between 0.4 and $1.4 \mathrm{~V}_{\mathrm{RHE}}$ in Ref. 49 was partially related to the dissolution of $\approx 60 \%$ of its initial Ni-content. Moreover, previous works on $\mathrm{Pt}-\mathrm{Cu}$ aerogels ${ }^{50}$ and carbon-supported Pt-Cu and Pt-Ni electrocatalysts ${ }^{49,51,52}$ have unveiled a correlation between the bulk phase non-noble metal content and the ORR activity that could explain this decrease of catalytic activity upon extended potential cycling.

To evaluate the possibility that the loss of Ni during the load-cycle AST may lead to the aerogel's ORR activity decrease, the catalyst layers and individual $\mathrm{Pt}_{3} \mathrm{Ni}$ nanochains were analyzed by SEM-EDX and TEM-EDX (three different locations each) to determine their $\mathrm{Ni}$ content (see Figure 6). The accuracy of the analysis is supported by the agreement of SEM and TEM data and the good match of the beginning-of-life $\mathrm{Ni}$ content values with the one derived from inductively coupled plasma-optical emission spectroscopy (ICP-OES) analysis in Reference 12 . As discernable from Figure 6, $\mathrm{Pt}_{3} \mathrm{Ni}$ aerogel suffers from the loss of $\approx 35 \%$ of its Ni content during start-stop AST vs. $\approx 60 \%$ in the load-cycle degradation test. The lower Ni loss in the start-stop AST is related to the passivation of Pt by the formation of a PtO surface layer that mitigates the dissolution of surface $\mathrm{Pt}$ and subsurface $\mathrm{Ni}$ when cycling the potential above $\approx 1.0 \mathrm{~V}_{\mathrm{RHE}} \cdot{ }^{24,53}$ The severe Ni leaching in the load-cycle test is a consequence of the observed Ostwald ripening phenomenon which constantly exposes $\mathrm{Ni}$ atoms from the nanochain interior to the corrosive PEFC environment. This effect can explain the mismatch between the ORR activity evolution of the $\mathrm{Pt}_{3} \mathrm{Ni}$ aerogel (cf. Figures $1 \mathrm{D} / 1 \mathrm{~F}$ ) and the predictions from the particle size effect introduced above. ${ }^{25,26}$ More precisely, Ni dissolution can lead to a positive shift of the catalyst's d-band center, thereby increasing the binding energy of oxygenated species and decreasing the ORR activity. ${ }^{54,55}$ To study other potential degradation effects associated with $\mathrm{Ni}$ leaching, such as ionomer poisoning in the membrane and catalyst layer, ${ }^{32}$ we performed BOL/EOL impedance measurements in $\mathrm{H}_{2} / \mathrm{N}_{2}{ }^{56,57}$ which showed a constant high frequency resistance with non-measurable proton transfer resistance along the catalyst layer (not shown here), ${ }^{18,58}$ thus preventing the quantification of possible changes in this last variable. Alternatively, Ni-loss may also lead to an increase in $\mathrm{O}_{2}$-transport resistance ${ }^{59}$ tentatively derivable from limiting current measurements ${ }^{60}-$ a possibility that will be within the focus of our forthcoming works.

\section{Conclusions}

In summary, we have investigated the behavior of unsupported $\mathrm{Pt}_{3} \mathrm{Ni}$ aerogel cathodes under start-stop and load-cycle ASTs in the

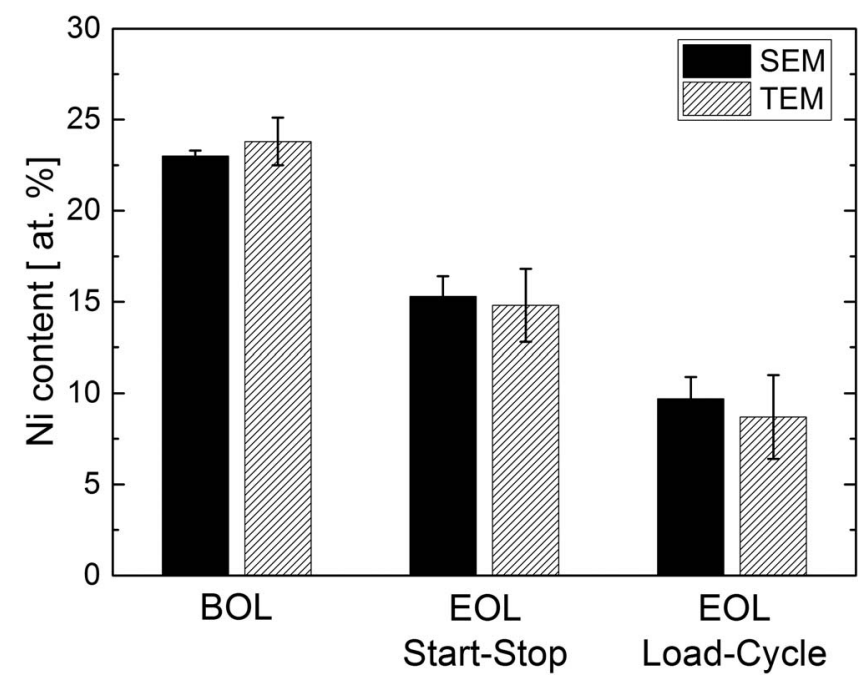

Figure 6. Average (from three locations) Ni content in at. \% from SEM-EDX (solid) and TEM-EDX analysis (shaded) at the beginning-of-life and after start-stop and load-cycle degradation. 
PEFC. Under start-stop degradation conditions, $\mathrm{Pt}_{3} \mathrm{Ni} \mathrm{MEAs}$ retain their BOL mass-specific activity, ECSA and high current density performance in $\mathrm{H}_{2}$ /air I/E curves after 10000 cycles, whereas $\mathrm{Pt} / \mathrm{C}$ shows $\mathrm{a} \approx 50 \% \mathrm{MA}$ and ECSA loss concomitant with a drastic performance reduction in $\mathrm{H}_{2} /$ air I/E curves. This superior durability of $\mathrm{Pt}_{3} \mathrm{Ni}$ aerogel vs. $\mathrm{Pt} / \mathrm{C}$ is related to the severe corrosion of the carbon support in the latter catalyst that leads to Pt nanoparticle detachment and collapse of the catalyst layer structure. For the load-cycle AST, both $\mathrm{Pt}_{3} \mathrm{Ni}$ and $\mathrm{Pt} / \mathrm{C}$ display a $\approx 50 \%$ reduction of the ECSA which is related to nanochain/nanoparticle size growth due to Ostwald ripening and particle migration/coalescence. The simultaneous decrease of MA and increase of SA for the Pt/C benchmark was found to be in excellent agreement with the well-known particle size effect on the ORR activity of $\mathrm{Pt}$ nanoparticles. For the $\mathrm{Pt}_{3} \mathrm{Ni}$ aerogel, though, the activity loss does not follow the same trend since, in addition to the increase in particle sizes, the catalyst also undergoes significant $\mathrm{Ni}$ dissolution $(\approx 60 \%)$ from the alloy phase which further decreases both MA and SA. Nevertheless, based on our results and the overall fuel cell power output in the course of both $\mathrm{AST}, \mathrm{Pt}_{3} \mathrm{Ni}$ aerogel is a promising PEFC catalyst for automotive application that warrants high durability in case of fuel starvation and cell start-up/shut-down events. To further improve its stability under normal PEFC operation, future work will focus on tuning the aerogel nanochain structure and surface vs. bulk composition, as to minimize $\mathrm{Ni}$ dissolution from the alloy catalyst. ${ }^{61}$

\section{Acknowledgment}

The authors thank Dr. Elisabeth Müller for assistance with electron microscopy experiments and ScopeM (ETH Zurich) for use of their facilities. The manuscript was written through contributions of all authors. All authors have given approval to the final version of the manuscript. This work was funded by the Swiss National Science Foundation (20001E_151122/1), the German Research Foundation (EY 16/18-1) and the European Research Council (ERC AdG 2013 AEROCAT). The authors declare no competing financial interests.

\section{References}

1. F. T. Wagner, B. Lakshmanan, and M. F. Mathias, J. Phys. Chem. Lett., 1, 2204 (2010).

2. C. Wang, M. Chi, D. Li, D. Strmcnik, D. van der Vliet, G. Wang, V. Komanicky, K. C. Chang, A. P. Paulikas, D. Tripkovic, J. Pearson, K. L. More, N. M. Markovic, and V. R. Stamenkovic, J. Am. Chem. Soc., 133, 14396 (2011).

3. A. Rabis, P. Rodriguez, and T. J. Schmidt, ACS Catal, 2, 864 (2012).

4. G. Ozouf, G. Cognard, F. Maillard, L. Guetaz, M. Heitzmann, and C. Beauger, ECS Trans, 69, 1207 (2015).

5. A. Patru, A. Rabis, S. E. Temmel, R. Kotz, and T. J. Schmidt, Catal. Today, 262, 161 (2016).

6. E. Fabbri, A. Rabis, R. Kotz, and T. J. Schmidt, Phys. Chem. Chem. Phys., 16, 13672 (2014).

7. E. Fabbri, A. Patru, A. Rabis, R. Kötz, and T. J. Schmidt, CHIMIA, 68, 217 (2014).

8. M. K. Debe, ECS Trans, 45, 47 (2012)

9. S. M. Alia, B. A. Larsen, S. Pylypenko, D. A. Cullen, D. R. Diercks, K. C. Neyerlin S. S. Kocha, and B. S. Pivovar, ACS Catal, 4, 1114 (2014).

10. S. M. Alia, S. Pylypenko, K. C. Neyerlin, D. A. Cullen, S. S. Kocha, and B. S. Pivovar, ACS Catal, 4, 2680 (2014)

11. S. M. Alia, K. Jensen, C. Contreras, F. Garzon, B. Pivovar, and Y. S. Yan, ACS Catal, 3, 358 (2013).

12. S. Henning, L. Kühn, J. Herranz, J. Durst, T. Binninger, M. Nachtegaal, M. Werheid, W. Liu, M. Adam, S. Kaskel, A. Eychmüller, and T. J. Schmidt, J. Electrochem. Soc., 163, F998 (2016).

13. O. Gröger, H. A. Gasteiger, and J. P. Suchsland, J. Electrochem. Soc., 162, A2605 (2015).

14. I. E. L. Stephens, J. Rossmeisl, and I. Chorkendorff, Science, 354, 1378 (2016).

15. A. Kongkanand, N. P. Subramanian, Y. Yu, Z. Liu, H. Igarashi, and D. A. Muller, ACS Catal., 6, 1578 (2016).

16. T. Tamaki, H. Kuroki, S. Ogura, T. Fuchigami, Y. Kitamoto, and T. Yamaguchi, Energy Environ. Sci., 8, 3545 (2015).

17. J. Lee, J. M. Yoo, Y. Ye, Y. Mun, S. Lee, O.-H. Kim, H.-W. Rhee, H. I. Lee, Y.-E. Sung, and J. Lee, Adv. Energy Mater, 5, 1402093 (2015).
18. S. Henning, H. Ishikawa, L. Kühn, J. Herranz, E. Müller, A. Eychmüller, and T. J. Schmidt, Angew. Chem. Int. Ed., (2017).

19. X.-Z. Yuan, H. Li, S. Zhang, J. Martin, and H. Wang, J. Pow. Sourc., 196, 9107 (2011).

20. C. Hartnig and T. J. Schmidt, J. Pow. Sourc., 196, 5564 (2011).

21. J. Speder, A. Zana, I. Spanos, J. J. K. Kirkensgaard, K. Mortensen, M. Hanzlik, and M. Arenz, J. Pow. Sourc., 261, 14 (2014).

22. T. Mittermeier, A. Weiß, F. Hasché, G. Hübner, and H. A. Gasteiger, J. Electrochem. Soc., 164, F127 (2017).

23. Fuel Cell Technical Team Roadmap, http://energy.gov/sites/prod/files/2014/02/f8/ fctt_roadmap_june2013.pdf.

24. M. Uchimura and S. S. Kocha, ECS Trans, 11, 1215 (2007).

25. P. J. Ferreira, G. J. la O', Y. Shao-Horn, D. Morgan, R. Makharia, S. Kocha, and H. A. Gasteiger, J. Electrochem. Soc., 152, A2256 (2005).

26. Y. Shao-Horn, W. C. Sheng, S. Chen, P. J. Ferreira, E. F. Holby, and D. Morgan, Topics Catal, 46, 285 (2007).

27. J. Suntivich, H. A. Gasteiger, N. Yabuuchi, and Y. Shao-Horn, J. Electrochem. Soc, 157, B1263 (2010).

28. P. Oberholzer and P. Boillat, J. Electrochem. Soc., 161, F139 (2014).

29. P. Oberholzer, P. Boillat, A. Kaestner, E. H. Lehmann, G. G. Scherer, T. J. Schmidt, and A. Wokaun, J. Electrochem. Soc., 160, F659 (2013).

30. P. Oberholzer, P. Boillat, R. Siegrist, A. Kästner, E. H. Lehmann, G. G. Scherer, and A. Wokaun, Electrochem. Comm., 20, 67 (2012).

31. J. Biesdorf, A. Forner-Cuenca, T. J. Schmidt, and P. Boillat, J. Electrochem. Soc. 162, F1243 (2015)

32. H. A. Gasteiger, S. S. Kocha, B. Sompalli, and F. T. Wagner, Appl. Catal. B: Environ., 56, 9 (2005).

33. S. S. Kocha, in Handbook of Fuel Cells, W. Vielstich, A. Lamm, and H. A. Gasteiger, Editors, John Wiley \& Sons, Ltd (2010).

34. B. Andreaus and M. Eikerling, in Device and Materials Modeling in PEM Fuel Cells, S. J. Paddison and K. S. Promislow, Editors, p. 41, Springer New York, New York, NY (2009).

35. N. Nonoyama, S. Okazaki, A. Z. Weber, Y. Ikogi, and T. Yoshida, J. Electrochem. Soc., 158, B416 (2011)

36. W. Gu, D. R. Baker, Y. Liu, and H. A. Gasteiger, in Handbook of Fuel Cells, W. Vielstich, A. Lamm, and H. A. Gasteiger, Editors, John Wiley \& Sons, Ltd (2010).

37. S. J. Ashton and M. Arenz, J. Pow. Sourc., 217, 392 (2012).

38. E. Guilminot, A. Corcella, F. Charlot, F. Maillard, and M. Chatenet, J. Electrochem. Soc., 154, B96 (2007).

39. H. Schulenburg, B. Schwanitz, N. Linse, G. n., G. Scherer, A. Wokaun, J. Krbanjevic, R. Grothausmann, and I. Manke, J. Phys. Chem. C, 115, 14236 (2011).

40. J. Durst, A. Lamibrac, F. Charlot, J. Dillet, L. F. Castanheira, G. Maranzana, L. Dubau, F. Maillard, M. Chatenet, and O. Lottin, Appl. Catal., B, 138, 416 (2013).

41. L. Castanheira, W. O. Silva, F. H. B. Lima, A. Crisci, L. Dubau, and F. Maillard, ACS Catal, 5, 2184 (2015).

42. L. Castanheira, L. Dubau, and F. Maillard, Electrocatal, 5, 125 (2014).

43. S. Cherevko, G. P. Keeley, S. Geiger, A. R. Zeradjanin, N. Hodnik, N. Kulyk, and K. J. J. Mayrhofer, ChemElectroChem, 2, 1471 (2015).

44. P. Jovanovič, A. Pavlišič, V. S. Šelih, M. Šala, N. Hodnik, M. Bele, S. Hočevar, and M. Gaberšček, Chem CatChem, 6, 449 (2014).

45. K. Kinoshita, J. Electrochem. Soc., 137, 845 (1990)

46. E. Fabbri, S. Taylor, A. Rabis, P. Levecque, O. Conrad, R. Kötz, and T. J. Schmidt, ChemCatChem, 6, 1410 (2014).

47. S. Taylor, E. Fabbri, P. Levecque, T. J. Schmidt, and O. Conrad, Electrocatalysis, 7, 287 (2016).

48. Q. Jia, J. Li, K. Caldwell, D. E. Ramaker, J. M. Ziegelbauer, R. S. Kukreja, A. Kongkanand, and S. Mukerjee, ACS Catal., 6, 928 (2016).

49. C. Baldizzone, L. Gan, N. Hodnik, G. P. Keeley, A. Kostka, M. Heggen, P. Strasser, and K. J. J. Mayrhofer, ACS Catal, 5, 5000 (2015).

50. S. Henning, L. Kühn, J. Herranz, M. Nachtegaal, R. Hübner, M. Werheid, A. Eychmüller, and T. J. Schmidt, Electrochim. Acta, 233, 210 (2017).

51. S. Mezzavilla, C. Baldizzone, A.-C. Swertz, N. Hodnik, E. Pizzutilo, G. Polymeros, G. P. Keeley, J. Knossalla, M. Heggen, K. J. J. Mayrhofer, and F. Schüth, ACS Catal, 6, 8058 (2016).

52. N. Hodnik, C. Jeyabharathi, J. C. Meier, A. Kostka, K. L. Phani, A. Recnik, M. Bele, S. Hocevar, M. Gaberscek, and K. J. Mayrhofer, Phys. Chem. Chem. Phys., 16, 13610 (2014).

53. A. A. Topalov, S. Cherevko, A. R. Zeradjanin, J. C. Meier, I. Katsounaros, and K. J. J. Mayrhofer, Chem. Sci., 5, 631 (2014).

54. V. R. Stamenkovic, B. S. Mun, M. Arenz, K. J. Mayrhofer, C. A. Lucas, G. Wang, P. N. Ross, and N. M. Markovic, Nat. Mater., 6, 241 (2007).

55. V. R. Stamenkovic, B. Fowler, B. S. Mun, G. Wang, P. N. Ross, C. A. Lucas, and N. M. Markovic, Science, 315, 493 (2007)

56. R. Makharia, M. F. Mathias, and D. R. Baker, J. Electrochem. Soc., 152, A970 (2005).

57. J. Gazzarri, M. Eikerling, Q. Wang, and Z.-S. Liu, Electrochem. Solid State Lett., 13, B58 (2010)

58. H. Kuroki, T. Tamaki, and T. Yamaguchi, J. Electrochem. Soc., 163, F927 (2016)

59. J. Durst, M. Chatenet, and F. Maillard, Phys. Chem. Chem. Phys., 14, 13000 (2012).

60. D. R. Baker, D. A. Caulk, K. C. Neyerlin, and M. W. Murphy, J. Electrochem. Soc., 156, B991 (2009)

61. S. M. Alia, C. Ngo, S. Shulda, M.-A. Ha, A. A. Dameron, J. N. Weker, K. C. Neyerlin, S. S. Kocha, S. Pylypenko, and B. S. Pivovar, ACS Omega, 2, 1408 (2017). 